\title{
Evaluation of the Pattern of EPIYA Motifs in the Helicobacter pylori cagA Gene of Patients with Gastritis and Gastric Adenocarcinoma from the Brazilian Amazon Region
}

\author{
Adenielson Vilar e Silva, ${ }^{1}$ Mario Ribeiro da Silva Junior, ${ }^{1,2}$ \\ Ruth Maria Dias Ferreira Vinagre, ${ }^{3}$ Kemper Nunes Santos, ${ }^{1,2}$ \\ Renata Aparecida Andrade da Costa, ${ }^{1,2}$ Amanda Alves Fecury, ${ }^{1,2}$ \\ Juarez Antônio Simões Quaresma, ${ }^{1,2}$ and Luisa Caricio Martinss ${ }^{1,2}$ \\ ${ }^{1}$ Laboratório de Patologia Clínica, Núcleo de Medicina Tropical, Universidade Federal do Pará, \\ Avenida Generalissimo Deodoro No. 92, Umarizal, 66095-360 Belém, PA, Brazil \\ ${ }^{2}$ Núcleo de Medicina Tropical, Laboratório de Patologia Clínica das Doênças Tropicais, Universidade Federal do Pará, \\ Belém, PA, Brazil \\ ${ }^{3}$ Departamento de Gastroenterologia, Hospital Ophir Loyola, Belém, PA, Brazil
}

Correspondence should be addressed to Luisa Caricio Martins; caricio@ufpa.br

Received 30 December 2013; Accepted 7 April 2014; Published 24 April 2014

Academic Editor: Rodrigo E. Mendes

Copyright (C) 2014 Adenielson Vilar e Silva et al. This is an open access article distributed under the Creative Commons Attribution License, which permits unrestricted use, distribution, and reproduction in any medium, provided the original work is properly cited.

\begin{abstract}
The Helicobacter pylori is associated with the development of different diseases. The clinical outcome of infection may be associated with the cagA bacterial genotype. The aim of this study was to determine the EPIYA patterns of strains isolated from patients with gastritis and gastric adenocarcinoma and correlate these patterns with the histopathological features. Gastric biopsy samples were selected from 384 patients infected with $H$. pylori, including 194 with chronic gastritis and 190 with gastric adenocarcinoma. The presence of the cagA gene and the EPIYA motif was determined by PCR. The cagA gene was more prevalent in patients with gastric cancer and was associated with a higher degree of inflammation, neutrophil activity, and development of intestinal metaplasia. The number of EPIYA-C repeats showed a significant association with an increased risk of gastric carcinoma $(\mathrm{OR}=3.79,95 \% \mathrm{CI}=$ 1.92-7.46, and $P=0.002$ ). A larger number of EPIYA-C motifs were also associated with intestinal metaplasia. In the present study, infection with $H$. pylori strains harboring more than one EPIYA-C motif in the cagA gene was associated with the development of intestinal metaplasia and gastric adenocarcinoma but not with neutrophil activity or degree of inflammation.
\end{abstract}

\section{Introduction}

Helicobacter pylori is a spiral Gram-negative bacterium that infects the stomach and causes chronic gastritis. In addition, the bacterium plays an important role in the pathogenesis of gastroduodenal ulcer and gastric carcinoma [1]. The diverse clinical outcomes of $H$. pylori infection depend on factors such as bacterial virulence, host susceptibility, and environmental factors [2].

Protein-associated gene A (CagA) is an important virulence factor of $\mathrm{H}$. pylori that is found in 70 to $80 \%$ of strains isolated in Brazilian cities and is associated with the development of peptic ulcers and gastric carcinoma [3, 4]. This protein is encoded by the cagA gene, which is located on the cag pathogenicity island (cag-PAI). After adhesion of cagA-positive $H$. pylori strains to the gastric epithelium, the CagA protein is injected directly into the host cell through a type IV secretion system encoded by the cag-PAI. Inside the epithelial cell, CagA is phosphorylated in its carboxyterminal region. This region is highly variable and contains a polymorphic pattern of Glu-Pro-Ile-Tyr-Ala amino acid repeats (EPIYA motif) $[5,6]$. Four types of EPIYA segments 
have been described (EPIYA-A, -B, -C, and -D) [7, 8]. CagA proteins always possess the EPIYA-A and EPIYA-B sites, but some proteins also contain one or more repeats of the EPIYA$\mathrm{C}$ site. This pattern is found normally in strains circulating in Western countries such as Europe, North America, and Australia (western CagA), whereas the presence of EPIYA-A and EPIYA-B sites, followed by the EPIYA-D site, has been described for $H$. pylori strains isolated in Asian countries $[6,8,9]$.

The EPIYA-C and -D motifs are the main sites for phosphorylation of CagA. Phosphorylated CagA forms a physical complex with SHP-2 phosphatase and triggers abnormal cellular signals that lead to the deregulation of cell growth, cell-to-cell contact, and cell migration, elongation of epithelial cells, and increased epithelial cell turnover, increasing the risk of acquiring precancerous genetic changes. The presence of the EPIYA-D motif or of multiple EPIYAC repeats is associated with increased SHP-2 phosphatase activity induced by CagA $[10,11]$. In Western countries, infection with strains carrying EPIYA-C repeats has been shown to predispose to the development of precancerous lesions and gastric cancer $[8,11]$.

Studies, conducted in Pará state, have demonstrated a high frequency of the cagA gene among circulating strains. In addition, CagA was found to be associated with peptic ulcers and gastric cancer $[3,12]$. However there are no studies of polymorphism of CagA in bacterial strains isolated in the Amazon region. And even in Brazil such studies are scarce $[13,14]$.

The objective of the present study was to determine the prevalence of variants of the $3^{\prime}$-region of the cagA gene among strains isolated from patients with chronic gastritis and gastric carcinoma and to investigate the association between these variants and histopathological features of the diseases.

\section{Materials and Methods}

2.1. Patients. Participated in the study were a total of 384 patients infected with $H$. pylori (222 men and 162 women) seen between May 2010 and June 2011 at Hospital Ophir Loyola, Belém, Pará, Brazil. All subjects included in the study were of the same socioeconomic level, had similar cultural habits, were born in the State of Pará, and had the same ethnic background (approximately 50\% Portuguese, 40\% Amerindian, and 10\% African) [15].

The study was approved by the Ethics Committee of the Tropical Medicine Center, Belém, Pará, Brazil. All patients gave their informed consent to participate in the study.

During endoscopy, two biopsies of the area adjacent to the lesion (perilesion) were obtained from patients with a suspicion of carcinoma for histological analysis and two antral biopsy specimens were obtained for analysis by molecular methods. Four antral biopsies (two for histological analysis and two for molecular analysis) were obtained from patients with gastritis.

2.2. Histological Analysis. The two antral biopsy specimens (one from the greater curvature and one from the incisura angularis) were fixed in $10 \%$ buffered formalin, embedded in paraffin, cut into sequential $0.4 \mu \mathrm{m}$ sections, and stained with hematoxylin and eosin. The biopsy specimens were analyzed by an experienced pathologist who was unaware of the clinical data of each patient. Histopathological parameters were graded from 0-3 (corresponding to absent, mild, moderate, and intense) using the criteria of the updated Sydney classification system [16] for chronic inflammation, polymorphonuclear activity, and intestinal metaplasia. Gastric carcinoma cases were classified using the Lauren classification [17].

2.3. Extraction of H. pylori Genomic DNA. Genomic DNA was extracted from the antral biopsy specimens using the PureLink Genomic DNA Mini kit (Invitrogen, São Paulo, Brazil).

2.4. Detection of H. pylori. PCR amplification for the detection of $H$. pylori DNA in gastric mucosa was performed as previously described [18]. Briefly, one set of primers (p1-F and p2-R) that amplify a fragment of $298 \mathrm{bp}$ of the $26-\mathrm{kDa}$ antigen gene present in all $H$. pylori strains was used for detection of the bacterium. The study included samples from patients in which bacterial DNA was isolated.

2.5. Amplification of the Constant Region of the cagA Gene. The constant region of the cagA gene was analyzed in samples positive for $H$. pylori. All patients positive for this region were then submitted to investigation of variable region (EPIYA) polymorphisms. The constant region of the cagA gene was amplified by the polymerase chain reaction (PCR) using the CagA/ConF $5^{\prime}$-GTGCCTGCTAGTTTGTCAGCG-3' ${ }^{\prime}$ and CagA/ConR $5^{\prime}$ TTGGAAACCACCTTTTGTATTAGC-3' primers [14]. Negative and positive controls were included in all reactions. The PCR products were separated by electrophoresis on $2 \%$ agarose gel that was stained with ethidium bromide and visualized under a UV transilluminator.

2.6. Amplification of the $3^{\prime}$-Variable Region of the cagA Gene and Determination of the EPIYA Pattern. The following primers described by Yamaoka et al. [19] were used for amplification of the $3^{\prime}$-variable region of the cagA gene: CAG1: $5^{\prime}$-ACCCTAGTCGGTAATGGGTTA- $3^{\prime}$ and CAG2: $5^{\prime}$-GTAATTGTCTAGTTTCGC-3'. The reaction consisted of $0.5 \mathrm{mM}$ of each primer, $1 \mathrm{X}$ PCR buffer, $1.5 \mathrm{mM} \mathrm{MgCl} 2$, sterile water, $0.2 \mathrm{mM}$ of each deoxynucleotide, $1.25 \mu \mathrm{L}$ Taq DNA polymerase (Invitrogen), and $2 \mu \mathrm{L}$ DNA in a final volume of $25 \mu \mathrm{L}$. The amplification conditions were initial denaturation at $95^{\circ} \mathrm{C}$ for $2 \mathrm{~min}$, followed by 35 cycles of denaturation at $95^{\circ} \mathrm{C}$ for $1 \mathrm{~min}$, annealing at $56^{\circ} \mathrm{C}$, and extension at $72^{\circ} \mathrm{C}$ for $1 \mathrm{~min}$, with a final extension at $72^{\circ} \mathrm{C}$ for $10 \mathrm{~min}$. PCR was carried out in a thermocycler GeneAmp PCR system 9700 (Applied Biosystems). Products of 500 to $850 \mathrm{bp}$ were obtained depending on the type and number of repeats of the EPIYA-C motif in the $\operatorname{cag} A$ gene. The PCR products were separated by electrophoresis on $2 \%$ agarose gel that was stained with ethidium bromide and visualized under a UV transilluminator. Positive controls of the different patterns of 
the EPIYA motif were used to confirm the PCR results. This methodology also allows the detection of mixed infection.

2.7. Sequencing of the $3^{\prime}$-Variable Region of cagA. PCR products were purified with the Wizard SV Gel and PCR Clean-Up System (Promega, Madison, MI) according to the manufacturer's recommendations. Purified products were sequenced using a BigDye Terminator v3.1 Cycle Sequencing Kit in an ABI 3130 Genetic Analyzer (Applied Biosystems, Foster City, CA). The sequences obtained were aligned using the CAP3 Sequence Assembly Program (available from: http://pbil.univ-lyonl.fr/cap3.php/). After alignment, nucleotide sequences were transformed into aminoacid sequences using the Blastx program (available from: http://blast.ncbi.nlm.nih.gov/Blast.cgi/) and compared to sequences deposited into the GenBank (http://www .ncbi.nlm.nih.gov/Genbank/).

2.8. Statistical Analysis. Odds ratios were calculated to evaluate the association of the cagA gene and EPIYA motifs with gastric diseases and histological parameters and the Mann Whitney $U$ test was used to compare frequencies, adopting a level of significance of $95 \%$. Statistical analysis was performed using the Biostat 5.0 program [20].

\section{Results}

A total of 384 patients with gastric symptoms and infected by H.pylori participated in the study. According to the histological report, $50.52 \%(194 / 384)$ of the patients had chronic gastritis and $49.48 \%(190 / 384)$ had gastric adenocarcinoma, including $32.11 \%$ (61/190) with the diffuse type and $67.89 \%$ $(129 / 190)$ with the intestinal type.

Age ranged from 18 to 63 years (mean: 37.2 years) for patients with chronic gastritis and from 27 to 90 years (mean: 59.9 years) for patients with gastric cancer. With respect to gender, there was a predominance of men in the two groups, with a frequency of $63.16 \%(120 / 190)$ in the cancer group and of $52.58 \%(102 / 194)$ in the gastritis group.

Investigation of the cagA gene in gastric biopsies showed that $256 / 384(66.7 \%)$ of the patients harbored strains carrying this gene. This frequency was higher among patients with adenocarcinoma $159 / 190(82.1 \%)$ than among those with gastritis 100/194 (51.5\%) (OR = 4.31, 95\%IC (2.70-6.87), $P<$ $0.01)$.

To examine the association between different patterns of EPIYA with gastric diseases and histopathological data was used only samples monoinfected.

3.1. Determination of the EPIYA Pattern of the cagA Gene and Its Association with Gastric Diseases. The distribution of the EPIYA genotypes is shown in Table 1 . The sequencing confirmed the results obtained by PCR and was not found EPIYA-D sites in the H. pylori strains studied.

Analysis of the different EPIYA motifs in the $3^{\prime}$-region of the cagA gene revealed that $58 \%(150 / 256)$ of the patients infected with cagA-positive $H$. pylori harbored strains with only one $\operatorname{cag} A$ EPIYA genotype (monoinfected) and $42 \%$
TABLE 1: Distribution of Helicobacter pylori cagA EPIYA genotypes in patients with chronic gastritis and gastric carcinoma.

\begin{tabular}{lccc}
\hline & EPIYA pattern & $\begin{array}{c}\text { Gastritis } \\
n(\%)\end{array}$ & $\begin{array}{c}\text { Cancer } \\
n(\%)\end{array}$ \\
\hline \multirow{4}{*}{ Monoinfection } & EPIYA-AB & $4(5.40)$ & $4(5.26)$ \\
& EPIYA-ABC & $42(56.76)$ & $19(25)$ \\
& EPIYA-ABCC & $26(35.14)$ & $25(32.90)$ \\
Mixed & EPIYA-ABC/ABCC & $20(76.92)$ & $33(41.25)$ \\
infection & EPIYA-ABC/ABCCC & - & $2(2.5)$ \\
& EPIYA-ABCC/ABCCC & $2(7.7)$ & $14(17.5)$ \\
& EPIYA- & $4(15.38)$ & $31(38.75)$ \\
\hline
\end{tabular}

$(106 / 256)$ presented mixed infection with strains carrying different $\operatorname{cag} A$ EPIYA genotypes (Table 1). The frequency of mixed infection was higher among patients with adenocarcinoma compared with those with gastritis $(\mathrm{OR}=2.99,95 \%$ IC (1.73-5.13), $P<0.01)$.

The analysis of the distribution of the EPIYA patterns in monoinfected patients showed that colonization by $H$. pylori CagA-positive with two or three EPIYA C motifs was more prevalent among patients with gastric adenocarcinoma (OR $=3.78,95 \%$ IC $(1.92-7.46), P=0.002)$.

3.2. Association between Presence of the cagA Gene and Histopathological Findings. When the histopathological findings of the patients colonized by CagA-positive strains (256/384) with those harboring CagA-negative strains $(128 / 384)$ were compared, a higher degree of gastric inflammation, neutrophil activity, and intestinal metaplasia was observed in the former (Table 2).

3.3. Association between the Numbers of EPIYA-C Segments and Histopathological Findings. The increased number of EPIYA-C segments was associated with the presence of intestinal metaplasia (Table 3) but not with the other histological parameters such as degree of inflammation and neutrophil activity (Table 4 ).

\section{Discussion}

The CagA protein is an important $H$. pylori virulence marker that is associated with diseases such as peptic ulcer and gastric carcinoma in Western countries [21, 22]. Studies conducted in different Brazilian states, including the State of Pará, have demonstrated a high prevalence of strains carrying the cag $A$ gene in the Brazilian population, as well as an association of these strains with peptic ulcer disease and gastric carcinoma $[3,12,23]$. Similar results were observed in the present study in which the prevalence of strains carrying the cagA gene was higher among patients with gastric adenocarcinoma than among those with gastritis.

In addition to the presence of the cagA gene, the type of EPIYA motif in the carboxy-terminal region of the gene 
TABLE 2: Association between the presence or absence of the cagA gene and the histopathological findings of the study participants.

\begin{tabular}{lccc}
\hline Histopathological finding & cagA gene & OR (95\% CI) \\
\hline $\begin{array}{l}\text { Degree of inflammation } \\
\quad \text { Mild }\end{array}$ & $39(15.23)$ & $50(39.06)$ & \\
$\quad$ Moderate to intense & $217(84.77)$ & $78(60.94)$ & $3.57(2.18-5.84)$ \\
Neutrophil activity & $51(20)$ & $94(73.44)$ & $11.11(5.48-22.30)$ \\
$\quad$ Mild & $205(80)$ & $34(26.56)$ & 0.0001 \\
$\quad$ Moderate to intense & $39(15.23)$ & $6(4.69)$ & $3.65(1.50-8.88)$ \\
Metaplasia & $217(84.77)$ & $122(95.31)$ & 0.0001 \\
$\quad$ Mild & & & \\
$\quad$ Moderate to intense & & & \\
\hline
\end{tabular}

TABLE 3: Association between EPIYA polymorphisms and the presence or absence of metaplasia in monoinfected patients with chronic gastritis and gastric carcinoma.

\begin{tabular}{|c|c|c|c|c|c|c|c|c|}
\hline & \multicolumn{2}{|c|}{ Gastritis } & \multicolumn{6}{|c|}{ Cancer } \\
\hline & \multicolumn{2}{|c|}{ Metaplasia } & \multirow[t]{2}{*}{ OR (95\% CI) } & \multirow[t]{2}{*}{$P$} & \multicolumn{2}{|c|}{ Metaplasia } & \multirow[t]{2}{*}{ OR $(95 \% \mathrm{CI})$} & \multirow[t]{2}{*}{$P$} \\
\hline & Present & Absent & & & Present & Absent & & \\
\hline EPIYA (AB or $A B C)$ & 1 & 46 & \multirow{2}{*}{$13.14(1.49-116.15)$} & \multirow{2}{*}{0.01} & 2 & 20 & \multirow{2}{*}{$5.00(1.0509-237.89)$} & \multirow{2}{*}{0.05} \\
\hline EPIYA (ABCC or ABCCCC) & 6 & 21 & & & 18 & 36 & & \\
\hline Total & 7 & 67 & & & 20 & 56. & & \\
\hline
\end{tabular}

TABLE 4: Association between EPIYA polymorphisms in the cagA gene and degree of inflammation and neutrophil activity in monoinfected patients.

\begin{tabular}{|c|c|c|c|c|c|c|}
\hline & \multirow{2}{*}{\multicolumn{2}{|c|}{$\begin{array}{l}\text { Degree of inflammation } \\
\text { EPIYA pattern }\end{array}$}} & \multicolumn{4}{|c|}{ Neutrophil activity } \\
\hline & & & \multirow[t]{2}{*}{$U(p)$} & \multicolumn{2}{|c|}{ EPIYA pattern } & \multirow[t]{2}{*}{$U(p)$} \\
\hline & $\mathrm{AB}$ or $\mathrm{ABC}$ & $\mathrm{ABCC}$ or $\mathrm{ABCCCC}$ & & $\mathrm{AB}$ or $\mathrm{ABC}$ & $\mathrm{ABCC}$ or $\mathrm{ABCCCC}$ & \\
\hline Gastritis & $2(1-3)$ & $2(1-3)$ & $217.50(0.52)$ & $2(1-3)$ & $2(1-3)$ & $280.50(0.41)$ \\
\hline Cancer & $2(1-3)$ & $2(1-3)$ & $592.50(0.88)$ & $2(1-3)$ & $2(1-3)$ & $569.00(0.67)$ \\
\hline
\end{tabular}

Mild (1); moderate (2); intense (3).

has recently been shown to influence the biological activity of CagA and the aggressiveness of $H$. pylori strains [11, 24]. A study conducted in Western countries demonstrated that the presence of bacterial strains with multiple repeats of the EPIYA-C motif predisposes to precancerous lesions and gastric cancer [24].

All patients in this study were natives of the state of Pará, and based on the study of Santos et al., 1999, the population of this state has an ethnic background of approximately 50\% Portuguese, 40\% Amerindian, and 10\% African. In Brazil, a continental country, there are few studies on this subject, this study being the first to evaluate the pattern of CagA EPIYA segments in the North region of the country.

In the present study strains with two or three repeats of the EPIYA-C motif were more frequent in patients with gastric adenocarcinoma. The risk of gastric cancer was approximately 4-fold higher among patients infected with cagA-positive strains carrying two or three EPIYAC motifs compared to patients infected with cagA-positive strains carrying no or only one EPIYA-C motif. Furthermore, a higher frequency of colonization with mixed strains harboring different types of EPIYA motifs was observed in patients with adenocarcinoma. Similar results have been reported by Batista et al. [13] who studied patients from Minas Gerais, Brazil.

Although several studies have demonstrated an association between infection with $H$. pylori strains harboring two or three EPIYA-C motifs and gastric cancer, no association could be established between the number of EPIYA-C repeats and increased gastric inflammation [24, 25].

In the present study a positive association was observed between cagA status and neutrophil activity, degree of inflammation, and intestinal metaplasia. However, there was no association between the number of EPIYA-C repeats and the degree of lymphocyte or neutrophil infiltration.

CagA has been associated with increased gastric inflammation characterized by high-grade leukocyte infiltration, which is a long-term risk factor for carcinogenesis since the intense oxidative process triggered by the disintegration of cells in the gastric mucosa releases potentially mutagenic substances [26, 27]. Some studies suggest that the number of EPIYA-C repeats is not associated with proinflammatory cytokine production but rather increases the binding to 
SHP-2, with consequent morphological changes in the cell that induce mucosal damage $[25,28]$.

\section{Conclusions}

H. pylori strains harboring two or three EPIYA-C motifs, which are a risk factor for gastric cancer, predominated in patients with adenocarcinoma and were associated with the development of intestinal metaplasia in the gastric mucosa.

\section{Conflict of Interests}

The authors declare that there is no conflict of interests regarding the publication of this paper.

\section{References}

[1] J. G. Kusters, A. H. M. Van Vliet, and E. J. Kuipers, "Pathogenesis of Helicobacter pylori infection," Clinical Microbiology Reviews, vol. 19, no. 3, pp. 449-490, 2006.

[2] K. M. Fock and T. L. Ang, "Epidemiology of Helicobacter pylori infection and gastric cancer in Asia," Journal of Gastroenterology and Hepatology, vol. 25, no. 3, pp. 479-486, 2010.

[3] R. M. F. Vinagre, T. C. D. O. Corvelo, V. C. Arnaud, A. C. K. Leite, K. A. D. S. Barile, and L. C. Martins, "Determination of strains of Helicobacter pylori and of polymorphism in the interleukin-8 gene in patients with stomach cancer," Arquivos de Gastroenterologia, vol. 48, no. 1, pp. 46-51, 2011.

[4] M. Q. F. Cavalcante, C. I. S. Silva, M. B. B. Neto et al., "Helicobacter pylori vacA and cagA genotypes in patients from northeastern Brazil with upper gastrointestinal diseases," Memórias do Instituto Oswaldo Cruz, vol. 107, no. 4, pp. 561-563, 2012.

[5] M. Selbach, S. Moese, C. R. Hauck, T. F. Meyer, and S. Backert, "Src is the kinase of the Helicobacter pyloricagA protein in vitro and in vivo," Journal of Biological Chemistry, vol. 277, no. 9, pp. 6775-6778, 2002.

[6] H. Higashi, R. Tsutsumi, A. Fujita et al., "Biological activity of the Helicobacter pylori virulence factor cagA is determined by variation in the tyrosine phosphorylation sites," Proceedings of the National Academy of Sciences of the United States of America, vol. 99, no. 22, pp. 14428-14433, 2002.

[7] Y. Furuta, K. Yahara, M. Hatakeyama, and I. Kobayashi, "Evolution of cagA oncogene of Helicobacter pylori through recombination," PLoS ONE, vol. 6, no. 8, Article ID e23499, 2011.

[8] L. A. Sicinschi, P. Correa, R. M. Peek Jr. et al., "cagA Cterminal variations in Helicobacter pylori strains from Colombian patients with gastric precancerous lesions," Clinical Microbiology and Infection, vol. 16, no. 4, pp. 369-378, 2010.

[9] P. Correa and M. B. Piazuelo, "Evolutionary history of the Helicobacter pylori genome: implications for gastric carcinogenesis," Gut and Liver, vol. 6, no. 1, pp. 21-28, 2012.

[10] H. Higashi, R. Tsutsumi, S. Muto et al., "SHP-2 tyrosine phosphatase as an intracellular target of Helicobacter pyloricagA protein," Science, vol. 295, no. 5555, pp. 683-686, 2002.

[11] M. Naito, T. Yamazaki, R. Tsutsumi et al., "Influence of EPIYArepeat polymorphism on the phosphorylation-dependent biological activity of Helicobacter pyloricagA," Gastroenterology, vol. 130, no. 4, pp. 1181-1190, 2006.
[12] L. C. Martins, T. C. De Corvelo Oliveira, S. Demachki et al., "Clinical and pathological importance of vacA allele heterogeneity and cagA status in peptic ulcer disease in patients from North Brazil," Memorias do Instituto Oswaldo Cruz, vol. 100, no. 8, pp. 875-881, 2005.

[13] S. A. Batista, G. A. Rocha, A. M. C. Rocha et al., "Higher number of Helicobacter pyloricagA EPIYA C phosphorylation sites increases the risk of gastric cancer, but not duodenal ulcer," BMC Microbiology, vol. 11, p. 61, 2011.

[14] C. A. Rota, J. C. Pereira-Lima, C. Blaya, and N. B. Nardi, "Consensus and variable region PCR analysis of Helicobacter priori $3 /$ region of cagA gene in isolates from individuals with or without peptic ulcer," Journal of Clinical Microbiology, vol. 39, no. 2, pp. 606-612, 2001.

[15] S. S. E. Batista, J. D. Rodrigues, A. K. Ribeiro-dos-Santos, and M. A. Zago, "Differential contribution of indigenous men and women to the formation of an urban population in the Amazon region as revealed by mtDNA and Y-DNA," American Journal of Physical Anthropology, vol. 109, no. 2, pp. 175-180, 1999.

[16] M. F. Dixon, R. M. Genta, J. H. Yardley et al., "Classification and grading of Gastritis: the updated Sydney system," American Journal of Surgical Pathology, vol. 20, no. 10, pp. 1161-1181, 1996.

[17] P. Lauren, "The two histological main types of gastric carcinoma: diffuse and so-called intestinal-type carcinoma. An attempt at a histo-clinical classification," Acta pathologica et microbiologica Scandinavica, vol. 64, pp. 31-49, 1965.

[18] M. Hammar, T. Tyszkiewicz, T. Wadstrom, and P. W. O’Toole, "Rapid detection of Helicobacter pylori in gastric biopsy material by polymerase chain reaction," Journal of Clinical Microbiology, vol. 30, no. 1, pp. 54-58, 1992.

[19] Y. Yamaoka, T. Kodama, K. Kashima, D. Y. Graham, and A. R. Sepulveda, "Variants of the 3' region of the cagA gene in Helicobacter pylori isolates from patients with different $H$. pylori-associated diseases," Journal of Clinical Microbiology, vol. 36, no. 8, pp. 2258-2263, 1998.

[20] M. Ayres, M. J. Ayres, D. L. Ayres, and A. S. Santos, Bioestat 3.0-Aplicações Estatísticas nas áreas das Ciências Biológicas e Médicas, Sociedade Civil Mamirauá MCT-CNPq, Belém, Brazil, 2003.

[21] C. Nogueira, C. Figueiredo, F. Carneiro et al., "Helicobacter pylori genotypes may determine gastric histopathology," American Journal of Pathology, vol. 158, no. 2, pp. 647-654, 2001.

[22] M. J. Blaser, G. I. Perez-Perez, H. Kleanthous et al., "Infection with Helicobacter pylori strains possessing cagA is associated with an increased risk of developing adenocarcinoma of the stomach," Cancer Research, vol. 55, no. 10, pp. 2111-2115, 1995.

[23] D. M. Queiroz, E. N. Mendes, G. A. Rocha et al., “cagA positive Helicobacter pylori and risk for developing gastric carcinoma in Brazil," International Journal of Cancer, vol. 78, no. 2, pp. 135139, 1998.

[24] D. Basso, C. Zambon, D. P. Letley et al., "Clinical relevance of Helicobacter pyloricagA and vacA gene polymorphisms," Gastroenterology, vol. 135, no. 1, pp. 91-99, 2008.

[25] R. M. Ferreira, J. C. Machado, M. Leite, F. Carneiro, and C. Figueiredo, "The number of Helicobacter pyloricagA EPIYA C tyrosine phosphorylation motifs influences the pattern of gastritis and the development of gastric carcinoma," Histopathology, vol. 60, no. 6, pp. 992-998, 2012.

[26] P. Correa, "Helicobacter pylori and gastric carcinogenesis," American Journal of Surgical Pathology, vol. 19, supplement 1, pp. S37-S43, 1995. 
[27] C. M. Thomazini, N. A. Pinheiro, M. I. Pardini, L. E. Naresse, and M. A. M. Rodrigues, "Infecção por Helicobacter pylori e câncer gástrico: freqüência de cepas patogênicas cagA e vacA em pacientes com câncer gástrico," Jornal Brasileiro de Patologia e Medicina Laboratorial, vol. 42, no. 1, pp. 25-30, 2006.

[28] R. H. Argent, M. Kidd, R. J. Owen, R. J. Thomas, M. C. Limb, and J. C. Atherton, "Determinants and consequences of different levels of cagA phosphorylation for clinical isolates of Helicobacter pylori," Gastroenterology, vol. 127, no. 2, pp. 514523, 2004. 

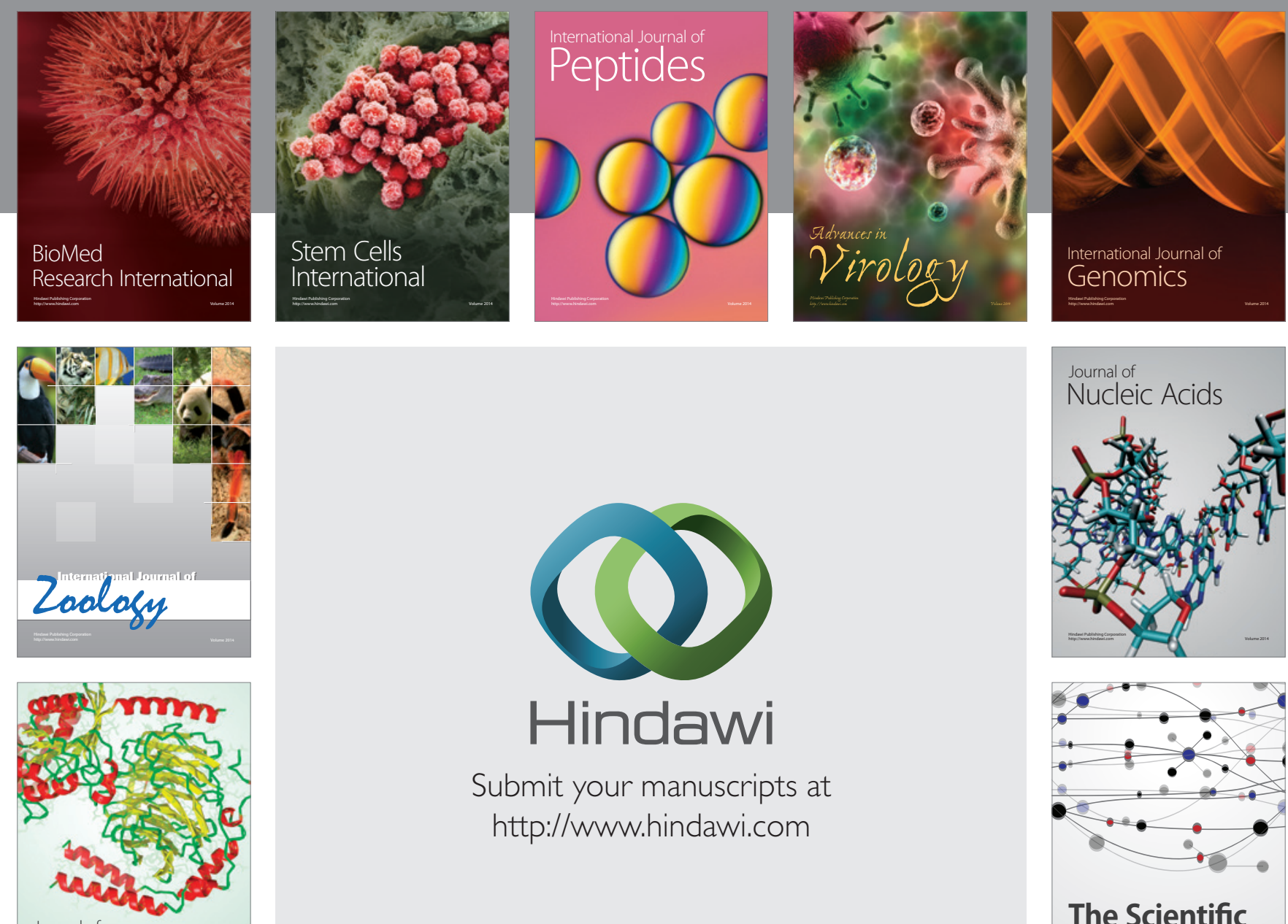

Submit your manuscripts at

http://www.hindawi.com

Journal of
Signal Transduction
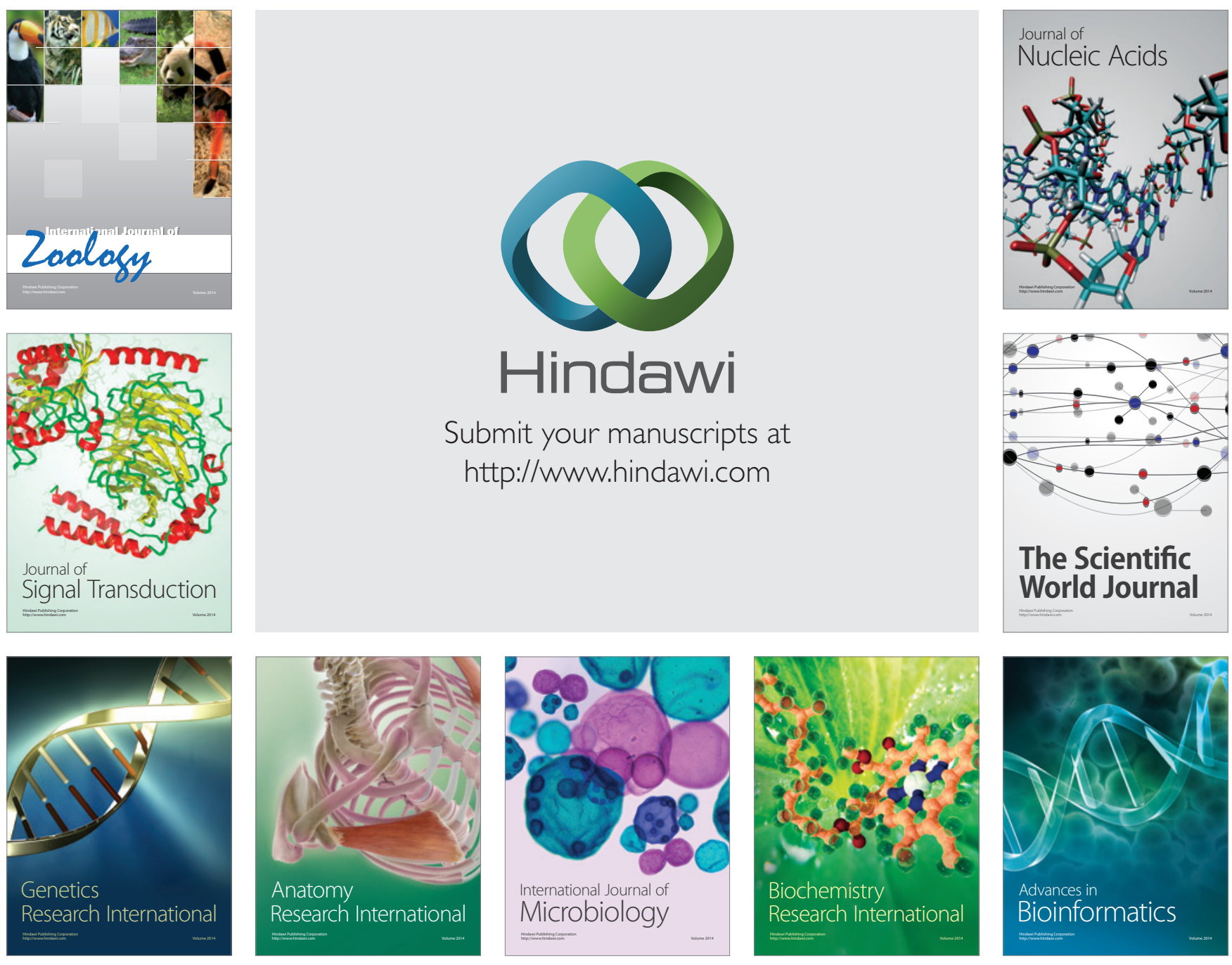

The Scientific World Journal
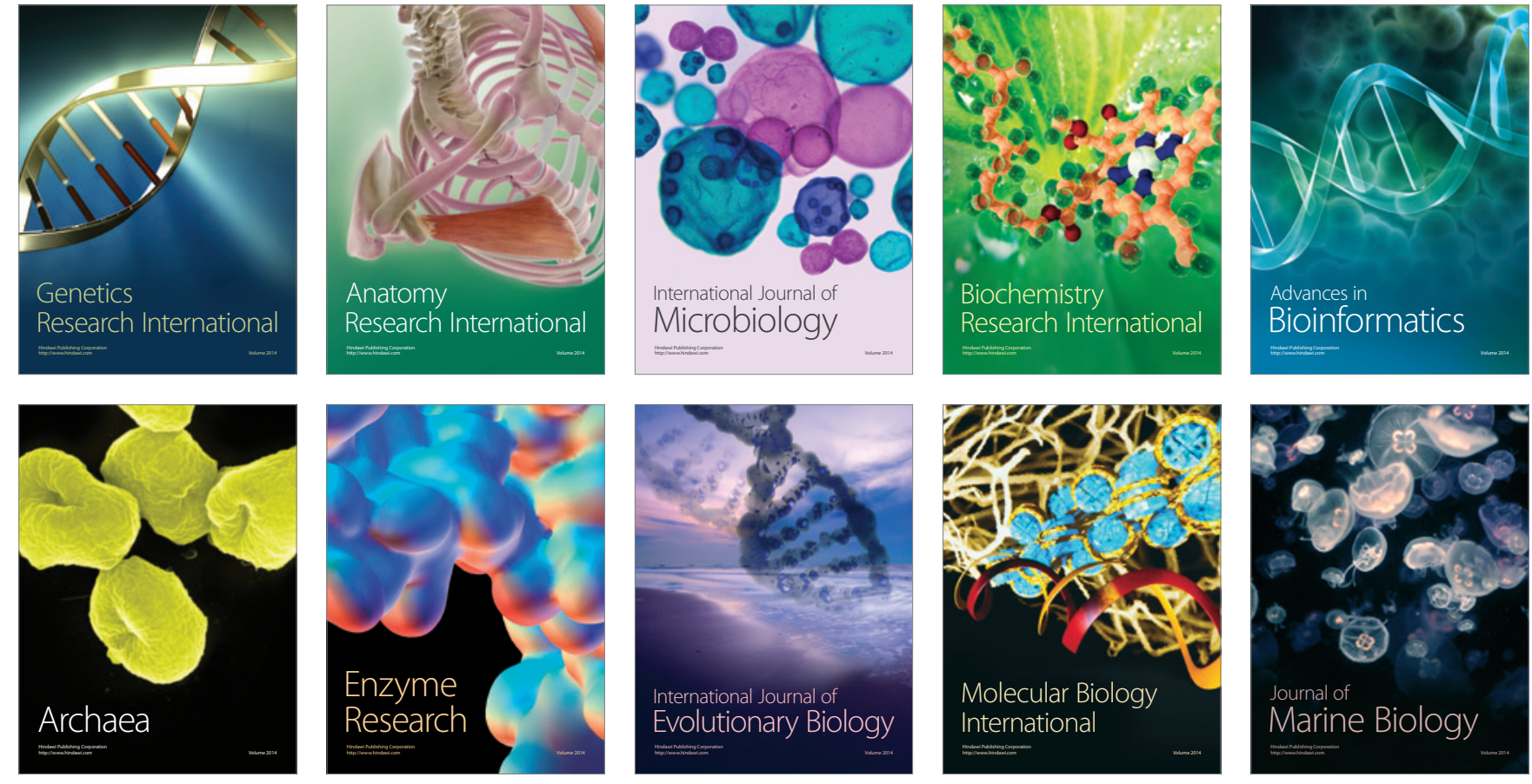